\title{
TINJAUAN PROSEDUR PENANGANAN SURAT KELUAR PADA DIVISI HUMAN CAPITAL DI KIMIA FARMA (PERSERO) TBK
}

\author{
Kristiana Widiawati ${ }^{1^{*}}$, Risyalwa Trisifa Andilla ${ }^{2^{*}}$ \\ Dosen Universitas Bina Insani ${ }^{1,2}$ \\ *kristiana@binainsani.ac.id ${ }^{l}$ \\ *risyalwatrisifa@gmail.com ${ }^{2}$
}

\begin{abstract}
ABSTRAK
Aktivitas penanganan surat di setiap instansi atau perusahaan menjadi salah satu kegiatan yang mendukung kegiatan utama di instansi atau perusahaan. Salah satu penanganan surat adalah surat keluar. Penangangan surat keluar harus dilaukan dengan baik karena berhubungan dengan pihak eksternal atau instansi lain. Prosedur penanganan surat yang baik merupakan salah satu peranan penting bagi kegiatan surat menyurat. Penanganan surat ini bertujuan agar surat terdokumentasi dengan rapih sehingga dapat ditemukan kembali dengan cepat dan mudah. Adapun manfaat penanganan surat apabila ditangani dengan baik yaitu surat-surat yang ditangani akan tercatat dengan baik, prosedur penanganan surat jelas, surat akan tersimpan baik sehingga mudah untuk ditemukan, rahasia isi surat akan terjaga. Penelitian dilakukan dengan menggunakan metode kualtitif dengan analisis secara deskriptif. Data primer yang diolah merupakan hasil obeservasi, interview atau wawancara dengan narasaumber pada bagian Unit Talent Acquisition divisi Human Capital. Prosedur penanganan surat keluar yang dilakukan oleh PT Kimia Farma (Persero) Tbk adalah penyiapan konsep surat, pengetikan dan penyuntingan surat, persetujuan surat, pengiriman surat. Hasil penelitian menyatakan bahwa prosedur penanganan surat keluar belum diterapkan sesuai dengan kebijakan perusahaan dimana prosedur yang diterapkan dianggap lebih ringkas dan lebih efektif. Prosedur penanganan surat keluar yang di perusahaan meliputi penyiapan konsep, pengetikan dan penyuntingan surat, persetujuan surat dan pengiriman surat.
\end{abstract}

Kata-kata Kunci: Prosedur, Penanganan surat, Surat Keluar, Konsep Surat.

\section{ABSTRACT}

The activity of handling letters in each agency or company is one of the activities that support the main activities of the agency or company. One of the handling of mail is outgoing mail. Outgoing mail handling must be done properly because it relates to external parties or other agencies. Good mail handling procedures are an important role for correspondence activities. The purpose of handling this letter is so that the letter is neatly documented so that it can be recovered quickly and easily. As for the benefits of handling letters if handled properly, namely the letters handled will be recorded properly, the procedures for handling letters are clear, the letters will be stored properly so that they are easy to find, the secret of the contents of the letters will be protected The research was conducted using a qualitative method with descriptive analysis. Primary data that is processed is the result of observations, interviews or interviews with sources in the Talent Acquisition Unit of the Human Capital division. The procedures for handling outgoing letters carried out by PT Kimia Farma (Persero) Tbk are preparation of letter drafts, typing and editing letters, letter approval, letter delivery. The results of the study stated that the procedure for handling outgoing mail had not been 
implemented in accordance with company policy where the procedures applied were considered more concise and more effective The procedure for handling outgoing mail in the company includes drafting, typing and editing letters, letter approval and letter delivery.

Keywords: Procedures, Mail Handling, Outgoing Mail, Draft Letter

\section{PENDAHULUAN}

Surat menyurat merupakan suatu kegiatan rutin yang dilakukan oleh organisasi atau perusahaan. Surat adalah salah satu alat komunikasi yang digunakan untuk menyampaikan suatu pesan atau informasi berasal dari pihak satu dengan pihak lainnya dalam bentuk tertulis. Setiap organisasi atau perusahaan menerapkan metode atau prosedur penanganan surat yang berbeda-beda. Penanganan surat harus dilakukan secara tertata dan tersusun rapih agar dapat memperlancar administrasi organisasi atau perusahaan tersebut. Apabila surat tidak ditangani dengan baik, penyebaran informasi akan terhambat atau mengalami kendala. Oleh karena itu penanganan surat harus berjalan dengan lancar agar tujuan organisasi atau perusahaan mudah tercapai.

Di setiap instansi tentunya melakukan kegiatan surat menyurat. Agar kegiatan surat menyurat dapat berjalan dengan baik, perlu adanya penanganan yang tertib dan terorganisir. Hal ini dimaksudkan agar kegiatan surat menyurat terhindar dari permasalahan yang mungkin terjadi dalam kegiatan surat-menyurat. Misalnya karena tidak ditangani dengan baik, surat menjadi menumpuk. Selain itu juga penanganan surat bertujuan agar surat tidak hilang, mencegah kebocoran informasi yang menyebabkan kerugian bagi sebuah instansi, dan agar sewaktu-waktu mudah menemukan kembali surat-surat yang diperlukan. Adanya penanganan yang terorganisir, dapat mencegah terjadinya permasalahan-permasalahan yang menghambat jalannya kegiatan suratmenyurat.

Surat masuk merupakan surat yang diterima oleh perusahaan dari pihak luar/eksternal dengan berbagai jenis surat. Surat keluar merupakan surat yang dibuat oleh perusahaan dan dikeluarkan untuk pihak luar/ekskternal perusahaan. Dengan demikian perlu adanya prosedur pengelolaan surat- surat tersebut.

Beberapa penelitian sebelumnya menyatakan pendapatanya seperti pada penelitian, yang diteliti oleh (Hidayat \& Jumiatin, 2016) mengatakan bahwa "Prosedur pengelolaan surat masuk dan keluar pada Kantor Kecamatan Pamulang bisa dikatakan baik dan lancar. Prosedur 
pengelolaan surat keluar pada Kantor Kecamatan Pamulang terdiri dari 1) pembuatan konsep surat, 2) persetujuan konsep surat, 3) pengetikan surat, 4) penandatanganan surat, 5) pencatatan surat, 6) pemberian cap dinas, 7) penyampulan surat, 8) pengiriman surat, 9) penyimpanan".

Demikian juga dibuktikan oleh hasil penelitian (Junaedi \& Historia, 2017) menjelaskan "Prosedur penanganan surat keluar di Lembaga Pendidikan SMP AlHasra masih sangat sederhana, menggunakan buku agenda surat keluar. Prosedur penanganan surat keluar di bagian tata usaha Lembaga Pendidikan SMP AlHasra ialah pembuatan konsep, pencatatan nomor, pengetikan surat, pencatatan nomor, pengoreksian kembali, stempel/cap, penggandaan, penyimpanan arsip, menulis buku ekspedisi dan pendistribusian”.

Penelitian lain yang dilakukan oleh (Purwandari, 2017) menyatakan tahapan dalam pengelolaan surat keluar yang diterapkan oleh Bagian Pengelolaan Dokumen BPK RI dimulai dari tahapan : Pembuatan konsep surat dimulai dari mengetahui perihal surat yang ingin dibuat dan untuk kemudian menerima konsep surat dari pejabat yang berwenang, Pengetikan surat dilakukan oleh staf Adm. Umum dengan tujuan memudahkan informasi didalam surat agar lebih jelas dan bisa dipahami, Penyuntingan surat dilakukan oleh Kasubag untuk diperiksa, jika surat sudah sesuai Kasubag langsung mendandatangani, kemudian staf Administrasi Umum memberikan nomor surat dan menstempel surat, Pelipatan dan penyampulan surat, staf menerima surat kemudian mengecek banyak dan tebalnya surat hal ini bertujuan agar surat tetap dalam keadaan yang baik ketika sudah sampai ke alamat yang dituju, Pembubuhan alamat surat dilakukan oleh staf AU mencetak alamat surat, tanggal surat, dan nomor surat beserta mencetak lembar pengantar berdasarkan wilayah yang dituju dan Pendistribusian surat didistribusi melalui staf Administrasi Umum atau POS dengan tujuan agar surat sampai pada alamat yang dituju.

PT Kimia Farma (Persero) Tbk adalah perusahaan industri farmasi pertama di Indonesia. Setiap harinya PT Kimia Farma (Persero) Tbk tentunya melakukan kegiatan surat menyurat dengan customer, supplier, dan lain-lain. Banyaknya surat yang ditangani perlu adanya penanganan yang baik dan terorganisir.

Berdasarkan uraian yang dijelaskan sebelumnya rumusan masalah yang akan diteliti dari penelitian ini adalah bagaimanakah prosedur penanganan surat keluar pada divisi Human Capital di PT Kimia Farma (Persero) Tbk. Adapun tujuan 
penelitian adalah untuk mengetahui prosedur penanganan surat keluar pada divisi Human Capital di PT Kimia Farma (Persero) Tbk.

\section{A. Surat}

Menurut Priansa dan Garnida (2015:97) menyatakan bahwa "surat adalah sarana untuk menyampaikan pikiran, isi hati, maksud, atau kehendak pada orang lain melalui Bahasa tulis dengan mempergunakan kertas sebagai sarannya".

Menurut (Gaol, 2015) menyatakan bahwa "surat adalah alat untuk menyampaikan suatu maksud secara tertulis. Surat merupakan peranan penting dalam penyampaian informasi yang tidak langsung".

Sementara pendapat (Dewi, 2019) menjelaskan bahwa Surat adalah sebuah alat komunikasi tertulis yang digunakan oleh pengirim untuk mengirimkan berita atau informasi kepada penerima. Surat juga memiliki fungsi dokumentasi yang berisi rekaman tentang aktivitas suatu organisasi. Surat pula dapat dijadikan sebuah bukti atau dasar untuk melakukan tindakan tertentu karena memiliki tanda keabsahan perintah yang kuat, yaitu tanda tangan pembuatnya. Oleh karena itu penanganan pengelolaan surat perlu mendapatkan perhatian yang tinggi, terutama pada kegiatan pengarsipan untuk menjaga agar surat dapat digunakan kapan saja.
Berdasarkan beberapa definisi dari para ahli dapat disimpulkan bahwa surat adalah alat komunikasi tertulis untuk menyampaikan informasi atau berita menggunakan kertas untuk saranannya.

\section{B. Jenis-Jenis Surat Keluar}

Menurut Nuraida (2014:62-65) ada banyak macam surat. Untuk memudahkan mengetahui macam dan jenisnya, surat dapat ditinjau dari berbagai segi, antara lain sebagai berikut.

1. Menurut wujudnya, yaitu kartu pos, warkat pos, surat bersampul, memorandum atau nota, telegram, dan wesel.

2. Menurut jumlah penerimanya, yaitu surat biasa, surat edaran, dan surat pengumuman.

3. Menurut urgensi pengiriman/penyelesaiannya, yaitu surat biasaa, surat segera, dan surat sangat segera.

4. Menurut tujuannya, yaitu surat pemberitahuan, surat perintah, surat permintaan, surat peringatan, surat panggilan, surat susulan, surat keputusan, surat laporan, surat perjanjian, dan surat penawaran.

5. Menurut sifat isi dan asalnya, yaitu surat niaga, surat dinas/jabatan, surat pribadi/keluarga, dan surat yang berisi masalah sosial. 
6. Menurut keamanan isi suratnya, yaitu surat sangat rahasia (SRHS), surat rahasia (RHS), dan surat biasa.

7. Menurut prosedur pengurusannya, yaitu surat masuk dan surat keluar.

\section{Tujuan Penanganan Surat Keluar}

Menurut (Laksmi, 2015) menyatakan bahwa "pengolahan surat umumnya melampui tahap-tahap tertentu yang tujuannya agar surat terdokumentasi dengan rapi sehingga dapat ditemukan kembali dengan cepat dan mudah".

\section{Manfaat Penanganan Surat Keluar}

Menurut (Endang, 2009) menyatakan bahwa "manfaat yang diperoleh apabila ditangani dengan baik : 1) surat akan tercatat dengan baik, 2) prosedur penanganan surat jelas, 3) surat akan tersimpan baik sehingga mudah untuk ditemukan, 4) rahasia akan terjaga".

\section{E. Sistem Pencatatan Surat Keluar}

Menurut Nuraida (2014:86-88) sistem pencatatan surat ada yang menggunakan secara manual maupun yang digital. Sistem pencatatan surat secara manual dapat dilakukan dengan memilih sistem-sistem dibawah ini.

1. Buku agenda, dapat berfungsi untuk mencatat surat masuk atau surat keluar. Mencatat surat masuk dan surat keluar dapat dipisahkan dengan menggunakan buku agenda surat masuk dan surat keluar, yang biasanya dibedakan pula tahunnya. Halaman-halaman dari buku ini berisi kolom-kolom (data) dari surat yang dicatat. Buku agenda juga digunakan sebagai alat bantu untuk mencari surat yang disimpan di file. Selain itu untuk pencatatan arsip surat masuk dan surat kelua, buku agenda juga dapat berguna untuk pencatatan dalam menelusuri arsip dokumen kantor lainnya.

2. Kartu kendali, pada prosedur pencatatan dan pendistribusian surat dengan mempergunakan kartu kendali, surat masuk digolongkan ke dalam surat penting, surat biasa, dan surat rahasia. Kartu kendali berfungsi sebagai pengganti buku agenda. Penggunaannya dapat ditulis rangkap dua, rangkap tiga, atau rangkap empat sesuai dengan kebutuhan.

3. Prosedur Tata Naskah, Takah atau suatu map jepit (snelchekter map) yang didalamnya berisi catatan kantor yang diedarkan oleh bagian adminstrasi kantor kepada orang/unit/pihak dalam organisasi yang mempunyai wewenang terhadap pengolahan catatan kantor yang bersangkutan. 
Sarana pengurusan surat yang berguna sebagai bukti tanda terima ada dua macam, yaitu sebagai berikut.

1. Buku ekspedisi. Buku ini dipergunakan sebagai tanda bukti penerimaan, pengiriman, atau pendistribusian surat atau barang.

2. Lembar pengantar surat, untuk mencatat surat masuk dan surat keluar yang biasa atau rahasia.

\section{F. Prosedur Penanganan Surat Keluar}

Menurut Nuraida (2014:91) mengatakan bahwa "kegiatan penanganan surat sebagai berikut.

1. Penyiapan Konsep, penulisan konsep dapat dilakukan sendiri oleh pejabat yang akan menandatangani surat tersebut tersebut atau staf yang ditunjuk.

2. Pengelompokkan, Surat-surat yang akan dikirim atau dibuat keluar dikelompokkan berdasarkan jenis suratnya, yaitu surat penting, biasa, atau rahasia.

\section{Pencatatan}

a) Surat keluar dicatat dalam buku agenda surat keluar yang terdiri atas kolom-kolom: nomor agenda, tanggal surat, nomor surat, perihal, keterangan, dan kepada atau tujuan. b) Pemberian nomor dan tanggal dilakukan setelah pengetikan surat dilaksanakan dan telah dibubuhi tanda tangan oleh yang berwenang serta siap dikirim.

c) Pemberian nomor dan kode dilaksanakan menurut pola klasifikasi yang telah ditetapkan.

d) Surat penting dicatat pada kartu kendali rangkap tiga.

e) Surat biasa dan surat rahasia dicatat pada lembar pengantar rangkap dua.

f) Pengiriman/Penyampaian/pendi stribusian, pengiriman surat keluar dilaksanakan oleh bagian ekspedisi, dapat menggunakan jasa pengiriman atau kurir

\section{METODE PENELITIAN}

Metode penelitian yang digunakan dalam penelitian ini adalah metode penelitian kualitatif, sumber data dalam suatu penelitian dimana subjek dari data diperoleh. (Tersiana, 2018)

Teknik pengumpulan data dalam suatu penelitian wawancara, observasi dan studi pustaka (Tersiana, 2018).

Jenis data yang digunakan dalam penelitian adalah data primer dan data sekunder. Data primer adalah data yang diperoleh harus diolah lagi, sedangkan data 
sekunder adalah data yang diperoleh tidak perlu diolah lagi. Data primer yang digunakan adalah data dari hasil wawancara. Data sekunder yang digunakan adalah buku agenda nomor surat, aplikasi penyimpanan surat, dan struktur organisasi PT Kimia Farma (Persero) Tbk.

Teknik pengumpulan data dalam penelitian ini adalah menggunakan teknik wawancara dengan Unit Talent Acquisition PT Kimia Farma (Persero) Tbk, observasi, dan studi pustaka dari berbagai macam sumber buku referensi untuk memperoleh referensi yang berkaitan dengan prosedur penanganan surat keluar.

Teknik analisis dalam penelitian ini adalah penelitian kualitatif yang menghasilkan data deskriptif berupa ucapan atau tulisan dan perilaku yang diamati mengenai prosedur penanganan surat keluar pada divisi Human Capital di PT Kimia Farma (Persero) Tbk

\section{KERANGKA BERPIKIR}

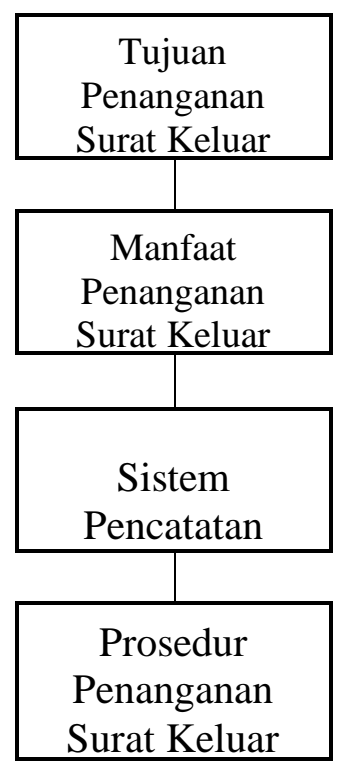

\section{HASIL DAN PEMBAHASAN}

Berikut hasil penelitian yang di peroleh melalui wawancara dengan PT Kimia Farma (Persero) Tbk sebagai berikut:

Berdasarkan hasil wawancara, jenisjenis surat keluar dalam PT Kimia Farma (Persero)Tbk yaitu surat undangan wawancara, surat undangan tes psikotes online, surat undangan tes kesehatan, surat undangan assessment, surat undangan presentasi dan wawancara, surat undangan offering letter, surat undangan tes tertulis online, dan surat panggilan kerja. Berdasarkan hasil wawancara, tujuan adanya penanganan surat keluar yaitu supaya informasi tersampaikan dengan jelas kepada penerima dan surat-surat tercatat dengan rapih. Berdasarkan hasil wawancara, manfaat dari penanganan surat keluar yaitu keamanan isi surat terjaga, surat keluar tercatat dengan rapih sehingga jika diperlukan tidak sulit untuk ditemukan

Berdasarkan hasil wawancara, jenisjenis surat keluar dalam PT Kimia Farma (Persero)Tbk yaitu surat undangan wawancara, surat undangan tes psikotes online, surat undangan tes kesehatan, surat undangan assessment, surat undangan presentasi dan wawancara, surat undangan offering letter, surat undangan tes tertulis online, dan surat panggilan kerja. Berdasarkan hasil wawancara, tujuan adanya penanganan surat keluar yaitu 
supaya informasi tersampaikan dengan jelas kepada penerima dan surat-surat tercatat dengan rapih. Berdasarkan hasil wawancara, manfaat dari penanganan surat keluar yaitu keamanan isi surat terjaga, surat keluar tercatat dengan rapih sehingga jika diperlukan tidak sulit untuk ditemukan.

Berdasarkan hasil wawancara, sistem pencatatan surat keluar yang digunakan yaitu buku nomor surat. Didalam buku surat ini terdiri kolom-kolom seperti tanggal pembuatan surat, nomor surat, perihal surat, dan tanggal tangan orang yang bersangkutan.

Berdasarkan hasil wawancara, prosedur penanganan surat keluar di PT Kimia Farma (Persero) Tbk sebagai berikut. 1) membuat konsep, 2) pengetikan dan penyuntingan surat, 3) persetujuan surat, 4) pengiriman surat.

Berikut adalah hasil analisis penelitian prosedur penanganan surat keluar pada divisi Human Capital di PT Kimia Farma (Persero) Tbk

\section{Jenis-Jenis Surat Keluar}

1. Ditinjau menurut wujudnya

Surat yang terdapat pada PT Kimia Farma (Persero) Tbk berupa surat elektronik, karena semua surat dibuat menggunakan komputer dan disimpan dalam bentuk pdf.

Berdasarkan teori dan hasil penelitian, wujud surat yang terdapat pada PT
Kimia Farma (Persero) belum menerapkan sesuai dengan teori, karena PT Kimia Farma (Persero) Tbk memiliki kebijakan tersendiri untuk menentukan wujud surat yang akan mereka gunakan

2. Ditinjau menurut jumlah penerimanya Berdasarkan hasil penelitian, surat yang terdapat pada PT Kimia Farma (Persero) Tbk berupa surat undangan wawancara, surat undangan tes psikotes online, surat undangan tes kesehatan, surat undangan assessment, surat undangan presentasi dan wawancara, surat undangan offering letter, surat undangan tes tertulis online, dan surat panggilan kerja. Jika ditinjau menurut jumlah penerimanya pada gambar 3.13, surat yang terdapat pada PT Kimia Farma (Persero) Tbk termasuk ke dalam surat biasa, karena surat ditujukan kepada orang/pejabat/instansi tertentu.

3. Ditinjau menurut urgensi pengiriman/penyelesaian

Berdasarkan hasil penelitian, surat yang terdapat pada PT Kimia Farma (Persero) Tbk seperti pada gambar di lampiran tiga sampai dengan sembilan, dalam surat undangan offering letter, surat undangan presentasi \& wawancara, surat undangan wawancara, dan surat undangan assessment terdapat kata "Wajib" untuk konfirmasi kehadiran dalam agenda yang akan 
dilaksanakan, dan di surat undangan presentasi \& wawancara di dalamnya terdapat batas waktu pengumpulan dokumen yang dibutuhkan sesuai dengan perihal surat tersebut.

Surat yang terdapat di lampiran tiga sampai dengan sembilan menuntut secepatnya untuk diketahui atau ditanggapi oleh penerima. Surat-surat tersebut termasuk ke dalam surat segera.

4. Ditinjau menurut urgensi pengiriman/penyelesaian.

Berdasarkan hasil penelitian, surat yang terdapat pada PT Kimia Farma (Persero) Tbk seperti pada gambar dilampiran tiga sampai dengan sembilan, dalam surat undangan offering letter, surat undangan presentasi \& wawancara, surat undangan wawancara, dan surat undangan assessment terdapat kata "Wajib" untuk konfirmasi kehadiran dalam agenda yang akan dilaksanakan, dan di surat undangan presentasi \& wawancara di dalamnya terdapat batas waktu pengumpulan dokumen yang dibutuhkan sesuai dengan perihal surat tersebut.

Surat yang terdapat di lampiran tiga sampai dengan sembilan menuntut secepatnya untuk diketahui atau ditanggapi oleh penerima. Surat-surat tersebut termasuk ke dalam surat segera. Surat yang terdapat pada PT Kimia Farma (Persero) Tbk termasuk ke dalam jenis surat pemberitahuan dan surat panggilan, karena surat tersebut berisikan informasi tentang pemberitahuan kepada penerima suatu agenda yang akan dilaksanakan, selain itu juga berisikan informasi panggilan kerja untuk penerima

5. Ditinjau menurut sifat isi dan asalnya

Hasil penelitian menyatakan, surat yang terdapat pada PT Kimia Farma (Persero) Tbk berisikan informasi tentang proses perekrutan dan seleksi calon pegawai.

PT Kimia Farma (Persero) Tbk belum menerapkan sesuai dengan teori, karena perusahaan memiliki kebijakan tersendiri untuk menentukan jenis surat apa yang akan mereka gunakan

6. Ditinjau menurut keamanan isi surat Berdasarkan hasil penelitian, surat yang terdapat pada PT Kimia Farma (Persero) Tbk yaitu surat undangan dan surat edaran. Surat undangan dan surat edaran termasuk ke dalam jenis surat biasa. Jika surat undangan dan surat edaran tersebut terbaca oleh orang lain tidak akan menimbulkan sesuatu akibat buruk atau merugikan organisasi atau pejabat yang bersangkutan.

7. Ditinjau menurut prosedur pengurusannya 
Berdasarkan hasil penelitian, surat yang terdapat pada PT Kimia Farma (Persero) Tbk yaitu surat undangan wawancara, surat undangan tes psikotes online, surat undangan tes kesehatan, surat undangan assessment, surat undangan presentasi dan wawancara, surat offering letter, surat undangan tes tertulis online, dan surat panggilan kerja.

Sesuai teori dan hasil penelitian, jenis-jenis surat yang terdapat di PT Kimia Farma (Persero) Tbk termasuk ke dalam surat keluar, karena surat yang terdapat di tempat penelitian ditujukan/atau dikirim oleh suatu bagian dalam perusahaan kepada bagian lain atau yang sama, atau kepada pihak eksternal baik orang/instansi/perusahaan lain di luar lingkungan internal perusahaan.

\section{Tujuan Penanganan Surat Keluar}

Tujuan penanganan surat keluar yang dijabarkan oleh Laksmi, bahwa tujuan pengolahan surat yaitu agar surat terdokumentasi dengan rapi sehingga dapat ditemukan kembali dengan cepat dan mudah.

Tujuan pengolahan atau penanganan surat menurut PT Kimia Farma (Persero) Tbk yaitu agar surat dapat tercatat dengan rapih supaya memudahkan dalam pencarian kembali surat yang diperlukan dan informasi yang disampaikan dari pihak pengirim kepada penerima jelas.

Sesuai teori dan hasil penelitian, dapat disimpulkan bahwa tujuan penanganan surat keluar bertujuan agar surat-surat tercatat dengan rapih sehingga mudah ditemukan kembali surat yang diperlukan. Dimana perusahaan sudah menerapkan teori-teori yang sudah dipaparkan.

\section{Manfaat Penanganan Surat Keluar}

Teori yang dipaparkan oleh Endang, mengatakan bahwa manfaat penanganan surat yaitu 1) surat akan tercatat dengan baik, 2) prosedur penanganan surat jelas, 3) surat akan tersimpan baik sehingga mudah untuk ditemukan, 4) rahasia akan terjaga.

Dari hasil wawancara dengan PT Kimia Farma (Persero) Tbk menyatakan bahwa manfaat penanganan surat bagi perusahaan yaitu surat-surat tercatat dengan rapih sehingga jika surat diperlukan kembali tidak sulit untuk ditemukan dan keamanan isi surat terjaga.

Sesuai teori dan hasil penelitian, hasil analisis manfaat penanganan surat keluar yaitu perusahaan sudah menerapkan teori-teori yang sudah dipaparkan, karena dengan adanya penanganan surat yang baik, surat-surat akan tercatat dengan rapih sehingga saat penemuan kembali surat yang diperlukan mudah untuk dicari dan penemuannya pun tidak membutuhkan 
waktu yang lama. Dengan adanya penanganan surat yang baik, surat-surat tidak akan hilang ataupun rusak.

\section{Sistem Pencatatan Surat Keluar}

Dari hasil penelitian, sistem pencatatan surat keluar yang digunakan PT Kimia Farma (Persero) Tbk yaitu buku nomor surat, di dalam buku surat ini terdiri kolomkolom seperti tanggal pembuatan surat, nomor surat, perihal surat, dan tanda tangan orang yang bersangkutan. Pencatatan surat keluar yaitu perusahaan belum menerapkan teori-teori yang sudah dipaparkan, karena PT Kimia Farma (Persero) Tbk hanya menggunakan sistem pencatatan dengan buku agenda nomor surat. Menurut perusahaan prosedur tersebut lebih efektif dan ringkas untuk kegiatan penanganan surat-menyurat . Akan tetapi perusahaan mempunyai kebijakan masing-masing untuk menentukan sistem pencatatan yang mereka gunakan

\section{Prosedur Penanganan Surat Keluar}

Dari hasil penelitian, prosedur penanganan surat pada divisi Human Capital di PT Kimia Farma (Persero) Tbk meliputi : penyiapan konsep, pengetikan dan penyuntingan surat, persetujuan surat, dan pengiriman surat. Prosedur penanganan surat keluar di PT Kimia Farma (Persero) Tbk tidak sepenuhnya menerapkan sesuai dengan teori, karena PT Kimia Farma (Persero) Tbk memiliki kebijakan tersendiri untuk menentukan prosedur penanganan surat yang akan mereka gunakan. Prosedur ini dianggap lebih ringkas dan lebih efektif, meliputi : penyiapan konsep, pengetikan dan penyuntingan surat, persetujuan surat, dan pengiriman surat.

\section{Tabel 1 Analisa Tinjuan Penanganan Surat Keluar}

\begin{tabular}{|c|c|c|c|}
\hline No & Teori & $\begin{array}{c}\text { Hasil } \\
\text { Penelitian }\end{array}$ & Analisa \\
\hline 1 & $\begin{array}{l}\text { Jenis-jenis } \\
\text { surat } \\
\text { menurut } \\
\text { Nuraida, } \\
\text { Diantara nya } \\
\text { yait0000u } \\
\text { ditinjau } \\
\text { menurut } \\
\text { wujudnya, } \\
\text { jumlah } \\
\text { penerima } \\
\text { nya, urgensi } \\
\text { pengiriman/ } \\
\text { penyelesaian } \\
\text { nya, } \\
\text { tujuannya, } \\
\text { sifat isi dan } \\
\text { asalnya, } \\
\text { keamanan isi } \\
\text { surat, dan } \\
\text { prosedur } \\
\text { penanganann } \\
\text { ya. }\end{array}$ & $\begin{array}{l}\text { Jenis-jenis } \\
\text { surat yang } \\
\text { terdapat di } \\
\text { PT Kimia } \\
\text { Farma } \\
\text { (Persero) } \\
\text { Tbk yaitu } \\
\text { surat } \\
\text { undangan } \\
\text { wawancara } \\
\text { undangan } \\
\text { tes psikotes } \\
\text { online, } \\
\text { surat } \\
\text { undangan } \\
\text { tes kesehatan, } \\
\text { kesat } \\
\text { surat } \\
\text { undangan } \\
\text { assessment } \\
\text { undangan } \\
\text { presentasi } \\
\text { dan } \\
\text { wawancara } \\
\text { offering } \\
\text { letter, surat } \\
\text { undangan } \\
\text { tes } \\
\text { tertulisonli } \\
\text { ne, dan } \\
\text { surat }\end{array}$ & 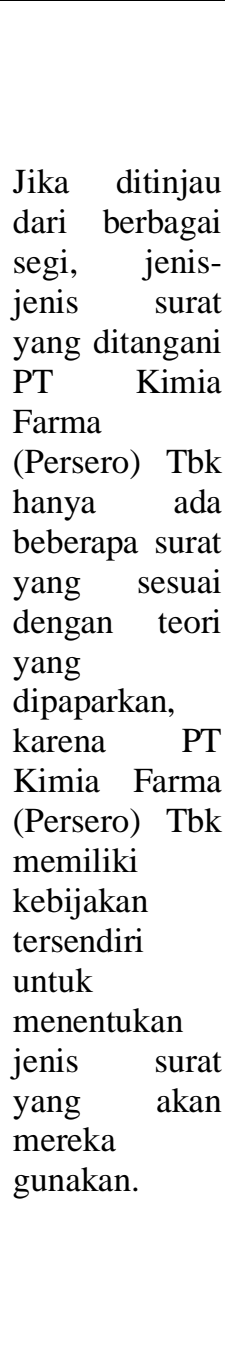 \\
\hline
\end{tabular}




\begin{tabular}{|c|c|c|c|}
\hline & & $\begin{array}{l}\text { panggilan } \\
\text { kerja. }\end{array}$ & \\
\hline 2 & $\begin{array}{l}\text { Tujuan } \\
\text { penanganan } \\
\text { surat } \\
\text { menurut } \\
\text { Laksmi } \\
\text { yaitu } \\
\text { bertujuan } \\
\text { agar surat } \\
\text { terdokumen } \\
\text { tasi dengan } \\
\text { rapi } \\
\text { sehingga } \\
\text { dapat } \\
\text { ditemukan } \\
\text { kembali } \\
\text { dengan } \\
\text { cepat dan } \\
\text { mudah. }\end{array}$ & $\begin{array}{l}\text { Tujuan } \\
\text { penangan } \\
\text { an surat } \\
\text { menurut } \\
\text { PT Kimia } \\
\text { Farma } \\
\text { (Persero) } \\
\text { Tbk yaitu } \\
\text { agar surat } \\
\text { dapat } \\
\text { tercatat } \\
\text { dengan } \\
\text { rapih } \\
\text { supaya } \\
\text { memudah } \\
\text { kan dalam } \\
\text { pencarian } \\
\text { kembali } \\
\text { surat yang } \\
\text { diperluka } \\
\text { n dan } \\
\text { informasi } \\
\text { yang } \\
\text { disampaik } \\
\text { an dari } \\
\text { pihak } \\
\text { pengirim } \\
\text { kepada } \\
\text { penerima } \\
\text { jelas. }\end{array}$ & $\begin{array}{l}\text { Tujuan } \\
\text { penanganan } \\
\text { surat PT } \\
\text { Kimia Farma } \\
\text { (Persero) } \\
\text { Tbk sudah } \\
\text { menerapkan } \\
\text { teori-teori } \\
\text { yang sudah } \\
\text { dipaparkan, } \\
\text { karena } \\
\text { bertujuan } \\
\text { agar surat- } \\
\text { surat tercatat } \\
\text { dengan rapih } \\
\text { sehingga } \\
\text { mudah } \\
\text { ditemukan } \\
\text { kembali surat } \\
\text { yang } \\
\text { diperlukan. }\end{array}$ \\
\hline 3 & $\begin{array}{l}\text { Manfaat } \\
\text { penanganan } \\
\text { surat keluar } \\
\text { menurut } \\
\text { Endang } \\
\text { yaitu 1) } \\
\text { surat akan } \\
\text { tercatat } \\
\text { dengan } \\
\text { baik, 2) } \\
\text { prosedur } \\
\text { penanganan } \\
\text { surat jelas, } \\
\text { 3) surat } \\
\text { akan } \\
\text { tersimpan } \\
\text { baik } \\
\text { sehingga } \\
\text { mudah } \\
\text { untuk } \\
\text { ditemukan, } \\
\text { 4) rahasia }\end{array}$ & $\begin{array}{l}\text { Manfaat } \\
\text { penangan } \\
\text { an surat } \\
\text { keluar } \\
\text { menurut } \\
\text { PT Kimia } \\
\text { Farma } \\
\text { (Persero) } \\
\text { Tbk yaitu } \\
\text { surat- } \\
\text { surat } \\
\text { tercatat } \\
\text { dengan } \\
\text { rapih, } \\
\text { sehingga } \\
\text { jika surat } \\
\text { diperluka } \\
\text { n kembali } \\
\text { tidak sulit } \\
\text { untuk } \\
\text { ditemuka } \\
\text { n dan }\end{array}$ & $\begin{array}{l}\text { Manfaat } \\
\text { penanganan } \\
\text { surat keluar } \\
\text { pada PT } \\
\text { Kimia Farma } \\
\text { (Persero) } \\
\text { Tbk sudah } \\
\text { menerapkan } \\
\text { teori-teori } \\
\text { yang sudah } \\
\text { dipaparkan, } \\
\text { karena } \\
\text { dengan } \\
\text { adanya } \\
\text { penanganan } \\
\text { surat yang } \\
\text { baik, surat- } \\
\text { surat akan } \\
\text { tercatat } \\
\text { dengan baik } \\
\text { dan rapih } \\
\text { sehingga saat }\end{array}$ \\
\hline
\end{tabular}

\begin{tabular}{|c|c|c|c|}
\hline & $\begin{array}{l}\text { akan } \\
\text { terjaga. }\end{array}$ & $\begin{array}{l}\text { keamanan } \\
\text { isi surat } \\
\text { terjaga. }\end{array}$ & $\begin{array}{l}\text { penemuan } \\
\text { kembali surat } \\
\text { yang } \\
\text { diperlukan } \\
\text { mudah untuk } \\
\text { dicari. }\end{array}$ \\
\hline 4 & $\begin{array}{l}\text { Sistem } \\
\text { pencatatan } \\
\text { surat } \\
\text { menurut } \\
\text { Nuraida } \\
\text { menggunak } \\
\text { an buku } \\
\text { agenda, } \\
\text { kartu } \\
\text { kendali, } \\
\text { dan } \\
\text { prosedur } \\
\text { tata naskah. } \\
\text { Sarana } \\
\text { pengurusan } \\
\text { surat yang } \\
\text { berguna } \\
\text { sebagai } \\
\text { bukti tanda } \\
\text { terima ada } \\
\text { dua macam } \\
\text { yaitu buku } \\
\text { ekspedisi } \\
\text { dan lembar } \\
\text { pengantar } \\
\text { surat. }\end{array}$ & $\begin{array}{l}\text { Sistem } \\
\text { pencatata } \\
n \quad \text { surat } \\
\text { keluar } \\
\text { yang } \\
\text { digunakan } \\
\text { PT Kimia } \\
\text { Farma } \\
\text { (Persero) } \\
\text { Tbk yaitu } \\
\text { buku } \\
\text { nomor } \\
\text { surat, di } \\
\text { dalam } \\
\text { buku surat } \\
\text { ini terdiri } \\
\text { kolom- } \\
\text { kolom } \\
\text { seperti } \\
\text { tanggal } \\
\text { pembuata } \\
\text { n surat, } \\
\text { nomor } \\
\text { surat, } \\
\text { perihal } \\
\text { surat, dan } \\
\text { tandatang } \\
\text { an orang } \\
\text { yang } \\
\text { bersangku } \\
\text { tan. }\end{array}$ & $\begin{array}{l}\text { Sistem } \\
\text { pencatatan } \\
\text { surat keluar } \\
\text { pada PT } \\
\text { Kimia Farma } \\
\text { (Persero) } \\
\text { Tbk tidak } \\
\text { sepenuhnya } \\
\text { menerapkan } \\
\text { teori-teori } \\
\text { yang sudah } \\
\text { dipaparkan, } \\
\text { karena } \\
\text { perusahaan } \\
\text { memiliki } \\
\text { kebijakan } \\
\text { tersendiri } \\
\text { untuk } \\
\text { menentukan } \\
\text { sistem pencatatan } \\
\text { pencis akan } \\
\text { yang s sistem } \\
\text { digunakan. } \\
\text { Menurut } \\
\text { perusahaan } \\
\text { menggunaka } \\
\text { n pencatatan } \\
\text { dengan buku } \\
\text { agenda } \\
\text { nomor surat } \\
\text { dianggap } \\
\text { lebih ringkas } \\
\text { dan efektif untuk } \\
\text { kegiatanpeng } \\
\text { ananan surat- } \\
\text { menyurat. }\end{array}$ \\
\hline 5 & $\begin{array}{l}\text { Menurut } \\
\text { Nuraida } \\
\text { prosedur } \\
\text { penanganan } \\
\text { surat keluar } \\
\text { meliputi } \\
\text { penyiapan } \\
\text { konsep, } \\
\text { pengelomp }\end{array}$ & $\begin{array}{l}\text { Prosedur } \\
\text { penangan } \\
\text { an surat } \\
\text { pada } \\
\text { divisi } \\
\text { Human } \\
\text { Capital di } \\
\text { PT Kimia } \\
\text { Farma }\end{array}$ & $\begin{array}{l}\text { Prosedur } \\
\text { penanganan } \\
\text { surat keluar } \\
\text { di PT Kimia } \\
\text { Farma } \\
\text { (Persero) } \\
\text { Tbk tidak } \\
\text { sepenuhnya } \\
\text { menerapkan }\end{array}$ \\
\hline
\end{tabular}




\begin{tabular}{|c|c|c|}
\hline $\begin{array}{l}\text { okkan } \\
\text { surat, } \\
\text { pencatatan } \\
\text { surat, dan } \\
\text { penyampai } \\
\text { an/pengiri } \\
\text { man/pendis } \\
\text { tribusian. }\end{array}$ & $\begin{array}{l}\text { (Persero) } \\
\text { Tbk } \\
\text { meliputi : } \\
\text { penyiapan } \\
\text { konsep, } \\
\text { pengetika } \\
\text { n dan } \\
\text { penyuntin } \\
\text { gan surat, } \\
\text { persetujua } \\
\text { n surat, } \\
\text { dan } \\
\text { pengirima } \\
\text { n surat. }\end{array}$ & $\begin{array}{l}\text { sesuai } \\
\text { dengan teori, } \\
\text { karena PT } \\
\text { Kimia Farma } \\
\text { (Persero) } \\
\text { Tbk } \\
\text { memiliki } \\
\text { kebijakan } \\
\text { tersendiri } \\
\text { untuk } \\
\text { menentukan } \\
\text { prosedur } \\
\text { penanganan } \\
\text { surat yang } \\
\text { akan mereka } \\
\text { gunakan. } \\
\text { Prosedur ini } \\
\text { dianggap } \\
\text { lebih ringkas } \\
\text { dan lebih } \\
\text { efektif, } \\
\text { meliputi } \\
\text { penyiapan } \\
\text { konsep, } \\
\text { pengetikan } \\
\text { dan } \\
\text { penyuntingan } \\
\text { surat, } \\
\text { persetujuan } \\
\text { surat, dan } \\
\text { pengiriman } \\
\text { surat. }\end{array}$ \\
\hline
\end{tabular}

Sumber: Hasil Penelitian, 2020

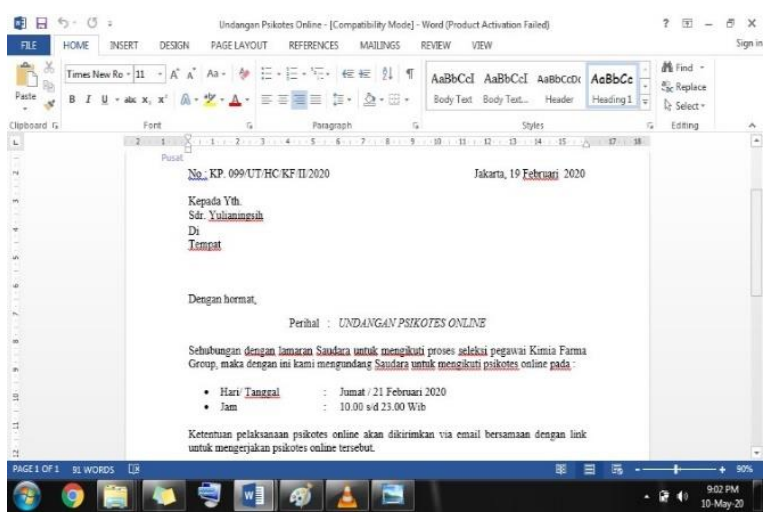

Sumber: PT Kimia Farma, 2020

Gambar 1 Konsep Surat

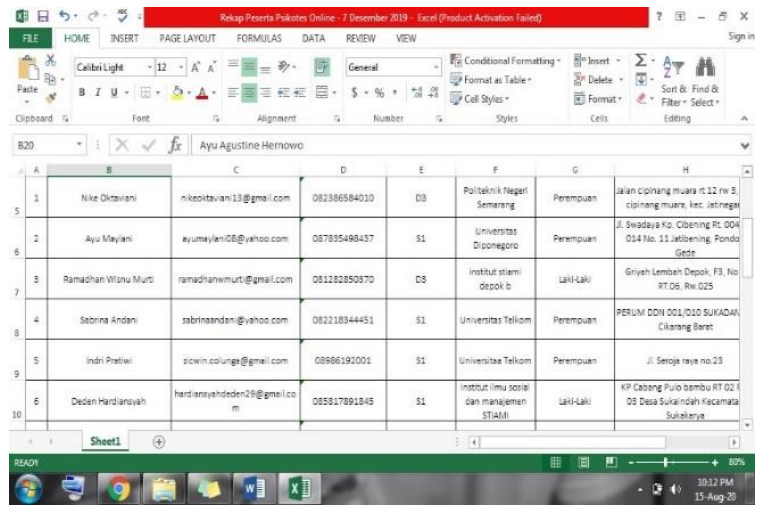

Sumber: PT Kimia Farma, 2020

Gambar 2 Data Penerima Surat

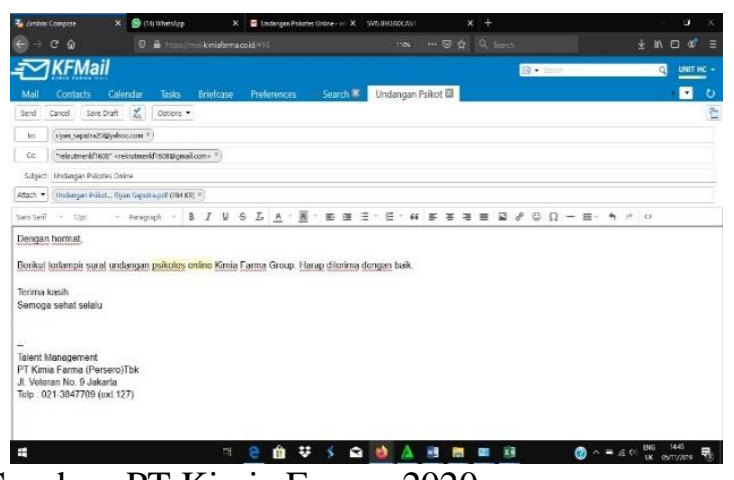

Sumber: PT Kimia Farma, 2020

Gambar 3 Tahap Pengiriman Surat

\section{SIMPULAN}

Berdasarkan hasil penelitian dan analisa yang dilakukan pada PT Kimia Farma (Persero) Tbk Prosedur penanganan surat keluar di PT Kimia Farma (Persero) Tbk tidak sepenuhnya menerapkan atau mengimplementasikan sesuai dengan teori, PT Kimia Farma (Persero) Tbk memiliki kebijakan tersendiri untuk menentukan prosedur penanganan surat yang akan mereka gunakan. Prosedur ini dianggap lebih ringkas dan lebih efektif, meliputi penyiapan konsep, pengetikan dan penyuntingan surat, persetujuan surat, dan 
pengiriman surat. Prosedur yang tidak lakukan oleh perusahaan yaitu pada tahapan pengelompokkan surat, karena prosedur yang sudah dilakukan terlalu panjang sehingga kebijakan perusahaan hanya menyanggupi prosedur tersebut

Saran bagai perusahaan dan penelitian lanjutan adalah sebagai berikut:

1. Penanganan surat ini sudah cukup baik dan perlu dipertahankan sesuai dengan kebijakan yang ditetapkan perusahaan.

2. Perlu adanya pencatatan surat keluar agar informasi mengenai surat yang akan dikirim lebih jelas dan lebih tercatat dengan rapih

\section{DAFTAR PUSTAKA}

Dewi, IK (2019) Pengelolaan Administrasi Surat Masuk Dan Surat Keluar Unit Kerja Baak Berbasis Web JURSIMA 7 (2) November 2019 https://ejournal.stmikgici.ac.id/index.php/j ursima/issue/view/18

DOI: https://doi.org/10.47024/js.v7i2.172

Endang (2009). Modul Menangani Surat Masuk dan Keluar (Mail Handling ). Erlangga.

Hidayat, S. \& Jumiatun, U. (2017). Prosedur Pengelolaan Surat Untuk Memperlancar Proses Penyampaian Informasi Pada Kantor Kecamatan Pamulang. Sekretari, 3(1), 33. https://doi.org/10.32493/skr.v3i1.637

Junaedi, E. \& Historia (2017) Prosedur Penangangan surat keluar di Bagian Tata Usaha Pada Lembaga Pendidikan SMP Al-Hasra Depok. Jurnal Sekretaris Vol 4 (1) hal $16-20$ https://doi.org/10.32493/skr.v4i1.606
Laksmi. (2015). Manjemen Perkantoran Modern (1st ed.). PT Raja Grafindo Persada

Nuraida I. (2014). Manajemen Administrasi Perkantoran (Indah Sri Utami (ed.). PT Kanisius.

Priansa DJ, Garnida A. (2015). Manajemen Perkantoran (M. M. Drs. Muhtarudin (ed.); 3rd ed.). Alfabeta

Purwandari, BS (2017). Implementasi Pengelolaan Surat Masuk dan Keluar di Badan Pemeriksa Keuangan Republik Indonesia Jurnal Utilitas Vol. 3 (1) hal 20.

Sugihastuti, FN. (2018). Surat Dinas: Teori dan Praktik (1st ed.). Pustaka Pelajar.

Tersiana A. (2018). Metode Penelitian (Sony Adams (ed.); 1st ed.). Penerbit Yogyakarta. 